\section{¿La diversidad funcional como una política del diseño?}

FUNCTIONAL DIVERSITY AS A POLITICS OF DESIGN?

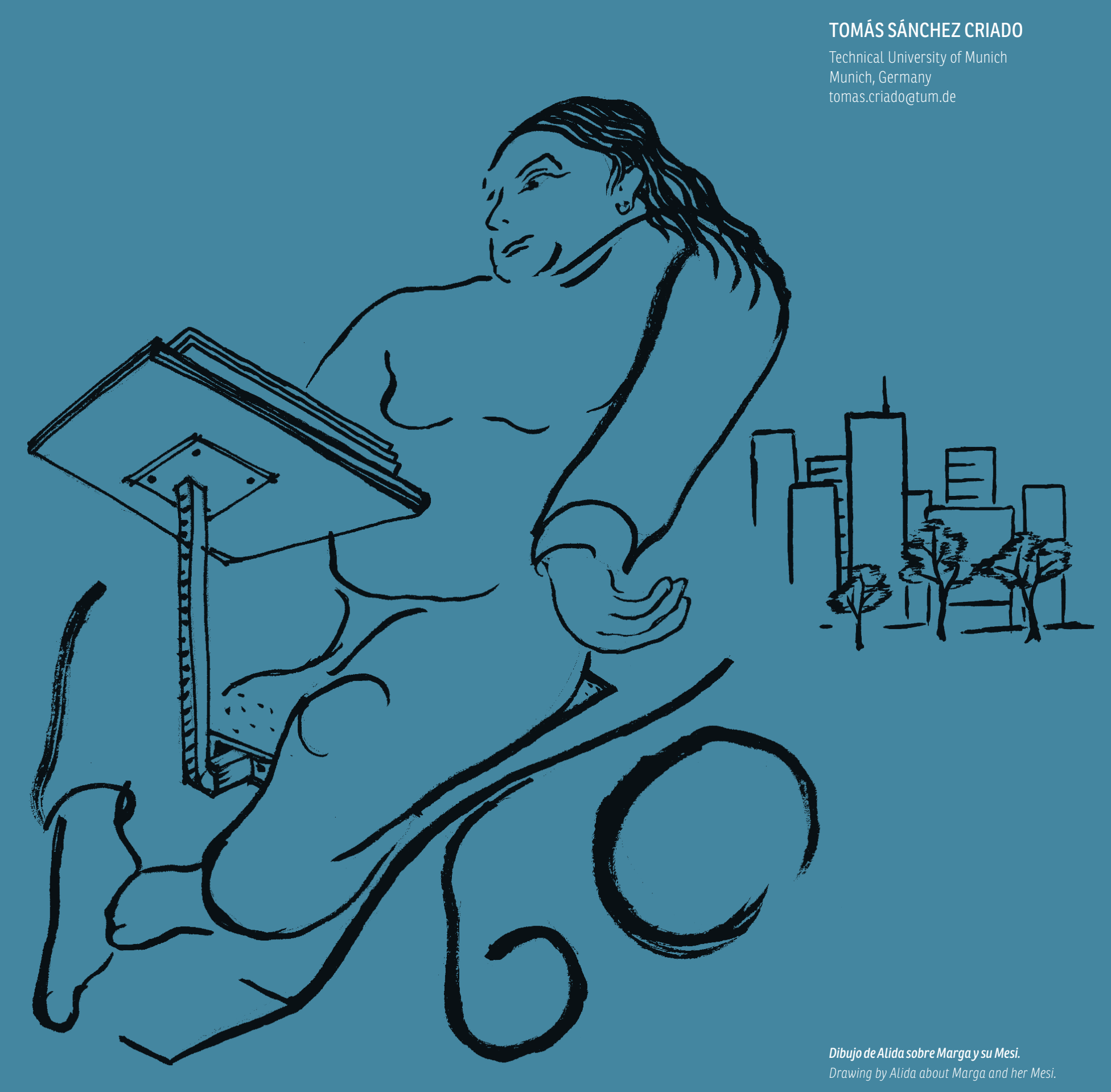

Este articulo es una indagación sobre el activismo de la "diversidad funcional" tras la ocupación de las plazas del 15-M españoly, y, más concretamente acerca de como a partir de ella la dresslad fancional se convierte en un nicas y entornos accesibles desarrollados de acuerdo con el modelo social de la discapacidad). Para apuntalar una lectura de la política del diseño - en el sentido de la fillosoffia politicica de Jacques Rancière- que ahí aparece, tomaré como caso un pequeño proyecto colaborativo desarrollado por colectivo

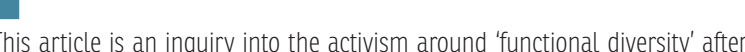

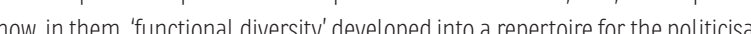
of design nnotably, the market of fechnical aids and accessible environments createc according to the social model of disability). To underpin the particular reading of the politics of design - in the sense developed by political phitilosopher Jaccu together by the Barcelona-based open design collective En torno a la silla! logentra by

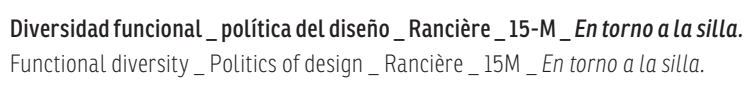

Introducción

En los últimos años, cualquier ámbito activista, cultural, académico o vinculado al diseño y la arquitectura en España ha sentido el impacto de "lo 15-M". Con este término quisiera designar no solo las movilizaciones de los indignados en torno al 15 de mayo de 2011, o las subsiguientes ocupaciones (localizadas e interconectadas a través de diferentes infraestructuras digitales) de numerosas plazas en ciudades españolas que durante meses aglutinaron y permitieron el contacto entre personas más o menos politizadas previamente, sino también los interesantes vínculos y nuevas formas de politización que ahí se forjaron para enfrentar lo que algunos han denominado una "crisis de régimen". Una crisis a la vez económica, político-institucional y cultural, pero también relativa al papel de los expertos y la ciudadanía, así como del significado del concepto de bienestar tras el pacto de la Transición democrática de 1978 (para una introducción somera, véase Moreno-Caballud, 2015; y para una reflexión sobre la conexión con otras estéticas de la protesta, véase Ramírez Blanco, 2014). Todas ellas cuestiones que intervienen en —o interpelan a — un cierto pacto modernista de utilidad pública del diseño (el diseño como la intervención de un saber experto en la materialización económica de una mejora del bienestar de la sociedad).
Introduction

In recent years, any domain in Spain, be it activist, cultural, academic or related to design and architecture, has felt the impact of the '15M'. This term not only designates the movement of the indignados of the $15^{\text {th }}$ of May 2011, or the subsequent public square occupations in numerous Spanish cities (localized and interconnected through different digital infrastructures, and bringing together people with more or less political activism background), but also the interesting connections and new forms of politicization that were forged there in order to face what some have called a 'regime crisis'. A crisis at the same time economic, politicalinstitutional and cultural: related to the role of experts and the citizenry, as well as to the meanings of welfare after the 1978's agreements that led to the 'Transition to Democracy' (for a brief introduction, see Moreno-Caballud, 2015; for a reflection on the connection with other aesthetics of revolt see Ramírez Blanco, 2014). All of these issues intervene in - or interpellate - a certain modernist agreement on the public utility of design (design conceived as the intervention of an expert know-how in the economic materialization of improvements in society's well-beingl. 
Pero si ya resultaría difícil poder explicar, a quienes no pudieron participar ahí, la brutal diversidad o la creatividad salvaje desplegada por tantas personas más allá de

representaciones reificadoras del acontecimiento poĺtíco más masivo, plural, multivocal y diverso que se recuerda en el país en las últimas décadas, iqué enorme reto poder contar algo de lo que su espíritu y modos de hacer trajero para repensar o, más bien, repolitizar el particular ámbito del diseño! A riesgo de incurrir en la hipérbole, asumiré aquî una mirada que pudiera parecer infinitesimalmente pequeña para intentarlo. Una mirada que no puede sino dejar fuera las muchísimas muestras de una transformación en curso en el ámbito del diseño y la arquitectura en España, como asi lo muestra la explosión inacabable de la arquitectura social y colaborativa surgida tras la debacle del boom de burbuja inmobiliaria y la subsiguiente defenestración del arquitecto estrella (Recetas Urbanas, 2010; López Munuera 2012). Mi mirada remite a un cruce de caminos que se ha hecho disponible en fechas recientes entre los ámbitos del "diseño abierto" y la "diversidad funcional". En este texto, introduciendo brevemente un proyecto desarrollado por el colectivo En torno a la silla (denominado La Mesi), quisiera hacer ver cómo el "diseño abierto desde la diversidad

funcional" pudiera suponer una política para el diseño (en el sentido empleado por el filósofo Jacques Rancière) ${ }^{1}$.

En lo que sigue, realizaré una contextualización práctica y terminológica de estos diferentes términos, para a continuación detallar ese proyecto en concreto. Y cerraré extrayendo algunas consecuencias prácticas del mismo, así como del cruce de caminos que encarna, para mostrar cómo el repertorio de la diversidad funcional politizaría el diseño (particularmente el diseño de ayudas técnicas y entornos arquitectónicos accesibles desarrollados según el modelo social de la discapacidad): abocándolo a una perpetua consideración de cómo asumir "la causa del otro", desbordando los límites que distinguen roles de "diseñador" y "usuario final" y abriéndolo a la infinita variedad corporal de formas de funcionamiento en producciones materiales más allá de la forma "objeto" o "producto".
But if it would already be difficult to explain, to those that could not take part there, the brutal diversity, or the savage creativity deployed by so many people - beyond any reifying representations of the most massive, plural, multivocal and diverse political event that the country can remember in the last few decades -, what an enormous challenge to be able to tell something about what its spirit and the ways of making brought along to rethink, or rather, re-politicize the specific area of design! At the risk of incurring in a hyperbole, I will adopt here a perspective that may seem infinitesimally small to attempt it. A perspective that cannot but leave out the many accounts of an ongoing transformation in the field of design and architecture in Spain, as demonstrated by the ongoing boom of social and collaborative architectures that emerged after the burst of the real estate bubble, and the subsequent defenestration of the star architect (Recetas Urbanas, 2010; López Munuera, 2012). My account will search to unravel a crossroads that has been made available recently between the areas of 'open design' and 'functional diversity'. In this text, and briefly introducing a project developed by the collective En torno a la silla (called La Mesi), I would like to show how 'design opened up from functional diversity' could imply a politics of design itself (in the sense entailed by philosopher Jacques Rancière) 2 . In what follows, I will convey a practical and terminological contextualization of these different terms, then jumping to describe this particular project. I will end extracting some practical consequences of what it means, as well as the crossroads it embodies, to show how the repertoire of functional diversity can politicize design (and, in particular, the design of technical aids and accessible architectura environments developed in continuity with the social mode of disability): namely, a perpetual concern about how to assume the 'cause of the Other' overflowing the boundaries that differentiate the roles of 'designers' and 'end users,' and opening up to the infinite variety in modes of bodily functioning engaging in material productions beyond the shape of the 'object' or the 'product'.

\section{LA DIVERSIDAD FUNCIONAL SE ENCUENTRA}

CON EL DISEÑO ABIERTO

En la primavera de 2011, tras los primeros días de ocupacion de las plazas de las distintas ciudades donde tuvieron lugar las movilizaciones del 15-M, al grito de "no queremos ser grupos empezaron a juntarse en "comisiones" temáticas (prensa, infraestructura, feminismo, pensamiento, etc.) que reportaban a la Asamblea General que tenia lugar cada día. Y en las principales acampadas, las de Madrid en la Puerta

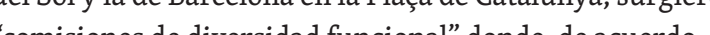
con Arenas y Pié (2014), tuvo lugar una particular forma politización del cuerpo en el espacio público. El concepto de "diversidad funcional" que estas comisiones convirtieron en tema central de sus exploraciones había sido acuñado y popularizado por el Foro de Vida Independiente y Divertad (FVID), una plataforma digital para el activismo en torno a la vida independiente que ha venido realizando un importan trabajo politico y de experimentación con formatos de

.

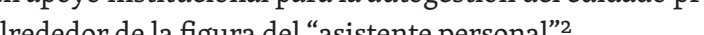
divergencia respecto del concepto de "discapacidal", proponiendo un nuevo término positivo para autorepresentarse (no centrado en la carencia, sino en diversidad), sino que disputa el marco "capacitista" según el cual unos cuerpos son léidos de acuerdo al saber médico-rehabilittador hegennonico como funcionalmente "discapaces. Pero el terrmino quiere ser algo más que discapacidad - según el cull las causas de lo dicsepacidod remiten a la organización simbólica y material del espacio social-. Al menos en el modo en que fue practicado en esas comisiones, quería trascender la adscripción identitaria por la que mucha gente lee simplemente una innovación terminologica que sustituiria el concepto de "discapacidad". Bien al contrario, se planteaba como una "lucha según la cual "todos somos diversos funcionales" (esto es, todos res y no siempre tipificables degún pas dus antropométricos) y donde debemos sentirnos interpelados por la discriminación que otros, iguales en esa condición compartida de diversidad funcional experimentan.

\section{FUNCTIONAL DIVERSITY MEETS}

OPEN DESIG

Spring of 2011: in the different cities where the $15 \mathrm{M}$ demonstrations took place, and after the first days of the squares' occupation - at the cry of "we don't want to be ds of politicians and bankers" different groups started to gather in thematic 'commissions' (press, infrastructure, feminism, thought, etc.) reporting to the everyday general assembly. 'In the main encampments, the ones in Madrid's Puerta del Sol and Barcelona's Plaça de

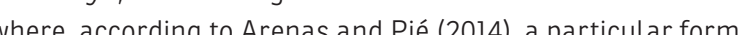
of politicization of the body in the public space took place. The concept of 'functional diversity' that these commissions Iransformed in the central theme of their explorations had been coined and popularized by the Foro de Vida Independiente y Divertad $^{3}(\mathrm{FV} V \mathrm{D})$ : a digital platform for independent-living activism, which has been doing important political work and engaging in different experiments with modalities of interdependence grounded on self-care, as well as fighting for the institutional support of se

The term 'functional diversity' not only points to a divergence with regards to the concept of 'disability'-putting foregrounding 'Lack' but 'diversity' in modes of functioning but also disputes the 'ableist' framework by which some bodies are read, according to the hegemonic ' $m$ edical-rehabilitative model', as functionally 'dis-able'. But the term wants to be more than a vernacular variant of the English 'social mode of disabilitity' - contending that the causes of disablement relate to the symbolic and material organization of our social spaces. At least in the manner in which it was practised in these framings by virtte of which many people understand 'function diversity' as a terminological innovation that would merely substitute the concept of 'disability'. Much on the contrary, it was proposed as a wider political struggle whereby 'we are all functionally diverse' (that is, we all function and move in a diversity of ways which are singular and not always typifyable according to some anthropometric patterns). A concern we shatd

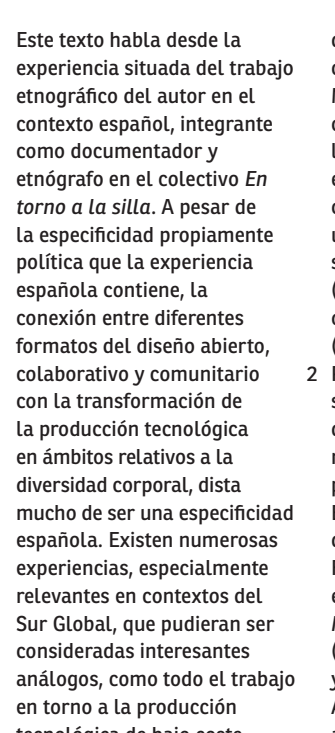

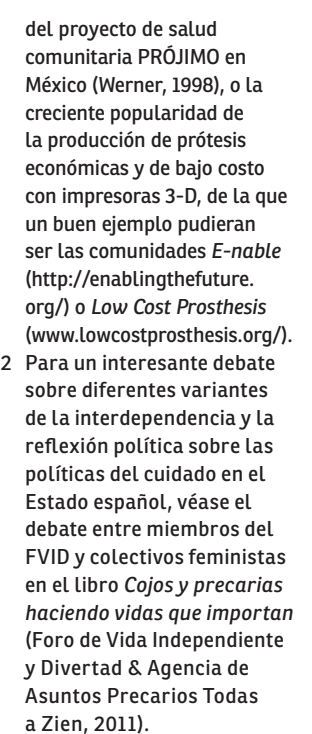

Asuntos Precantos
a z Zien, 2011.

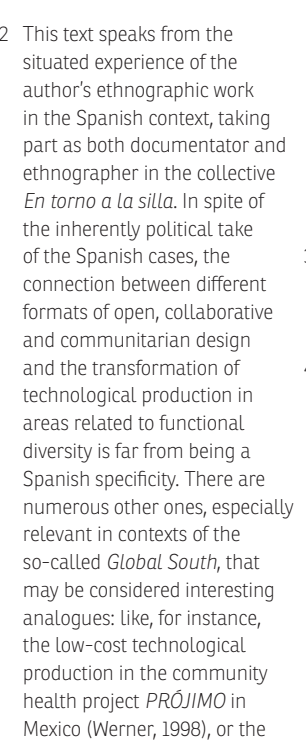

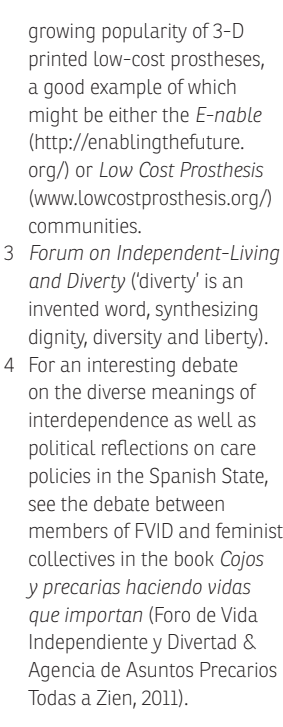




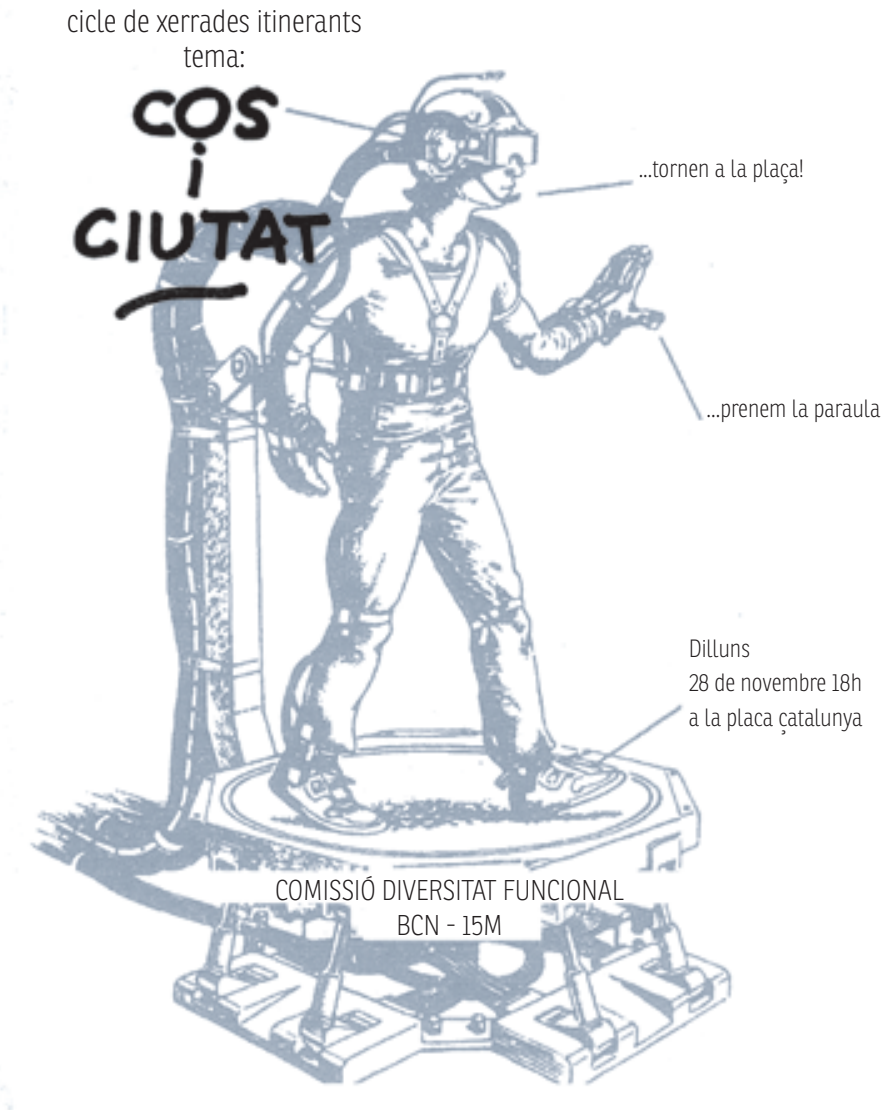

Este marco político de la «creación local de un caso de universalidad, por decirlo al modo de Rancière (1999, pág. 139), se hizo patente en una composición heterogénea de esas comisiones, que no solo unían a gente que iba y vena, sho que tena d los sectores social y sanitaio ar cono diferentes peso con un trasfondo político más o menos desarrollado, con saberes heterogéneos y diversos (entre los cuales se contab "manitas", diseñadoras y arquitectas), que se sintieron interpeladas por esta politización corporal más allá de discapacidad y su entramado institucional y mercantil. Pero aunque las comisiones generaron distintos debates, exploraciones e intervenciones públicas en el tejido de las asambleas generales, quisiera señalar aquí un particular eje de las reflexiones que ahi se hicieron preeminentes alrededor del nexo cueppo cudad, donde una preocupacion ten tonnal diseño uno de los tascente y ciudad" en noviembre de 2011 (de la comisión de diversidad funcional de Barcelona), de la que podrímos extractar a "temas para alimentar el debate" publicados en su blog:

«- La comisión de diversidad funcional constituye
una experiencia urbana donde se hace posible un vinculo politico. Cada vez que estamos juntos: creamos, sostenemos, llevamos con nosotros el espacio público. espacio urbano (...).
Cartel de "Cos Cilitat / Cuerpoy ciudad", charla itinerante organiziada por la Comiss

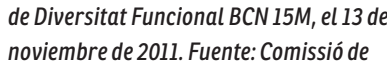
D versitat Funcional BCN 15 . Publicad hittps://diversitatafuncionallism.wordpress.

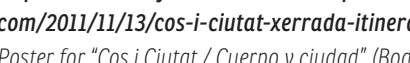
and city), titinerating lecture organizized by the Commisision for Functional Diversity BCN .15M. for functional Diversity BCN $15 \mathrm{Mm}$. Published

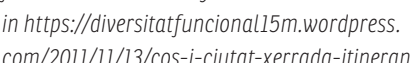

This politicisation, an exemplar of "the local and singular construction of cases of universality "to put it in the manner of Rancière (1999, p. 139), was made evident in a heterogeneous composition of those commilssions, which not only brought together people coming anda going, but also why dirterent social services and health professionals, as well as different people with more or less developed political backgrounds as well as heterogeneous and diverse knowledges (e.g. craftspeople, designers, and architects) who felt appealed by this embodied politicisation beyond 'disability', as well as its institutional and market frameworks.

Even though the commissions generated diverse debates, explorations and public interventions in the making of the general assemblies, I would like to point out here a particular set of concerns around the body-city nexus, which began to This was, for instence, one of the man of gadgets and spaces. in Barcelon's Functional Diversity Commission itinerats lecture 'Cuerpo y ciudad' (Body and City) in November 2011, from which we can extract some 'food for thought' published in their blog:

"- The Functional Diversity Commission constitutes an urban experience whereby a political bond is made possible. Every time we are together we create, we sustain, we carry public space with us. Together we have created bonds of itinerant solidarity in urban spaces (....
- esa experiencia humanizamos el espacio urbano: apropiandononos de él hablamos de sus dimensiones, sus barreras para decidir entre ta ciudad, eliminamos dirección e intensidad de nuestros movimientos. Decimos: es la ciudad la que debe adaptarse a nosotros y no las mujeres y hombres a ella.

- Habitando la calle demostramos que todos somos diversos (...). No somos especiales, tampoco estánd

no somos normales, tampoco una anomalía. (...)

- Discurrimos por la ciudad: por ella vamos, pensando con el cuerpo, vamos con el politizando la calle. Som entre nuestros cuerpos.

- Desplazándonos por la ciudad nos desplazamos tambié de los roles sociales, de los hábitasts segregados de los palabras que nos nombran y no son nuestras palabras. Hemos salido hace rato de casa y no volveremos siendo los mismos.

Hemos abandonado los territorios sin salida que nos estaban asignados

(Cosmisiobigadost

En paralelo, el grupo de trabajo sobre Diversidad Funciona de la Acampada Sol de Madrid publicó otra intervención espacial, de cariz más metodolóógico: una guía sobre "cómo

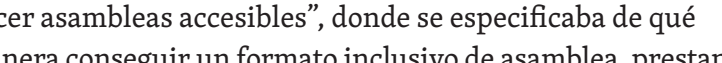
tención a diferentes dinás inclusivo de asamblea, prestando como relativas al lenguaje y los modos de interacción 4 .

Si prestamos atención a estas dos cuestiones, quizá no nos sorprenda saber que participantes de estas dos comision

presentaron y desarrollaron sendas propuestas para la

"Convocatoria para proyectos Funcionamiens. Diseños abiertos

Madrid (institución del Ayuntamientode Madrid pero sobre todo

uno de los espacios de dinamización de las discusiones y prácticas en torno al diseño abierto y la cultura libre), y que tenía por objeto recoger " "propuestas que planteen el diseño de objetos, entorno y herramientas desde la perspectiva de la diversidad funcional, del diseño abierto y de los estandares abiertos"s. Estas propuestas ueron desarroulladas con una pequeña financiación de Medial asicomo presentadasy dis a rido al calor de esa convo un kit para activar otras relaciones entre la silla de ruedas, su ocupantes, los entornos y las alianzas que habían empezado a florecer en el 15-M; un proyecto que contaba con diferentes integrantes de la comision de diversidad funcional del 15-M de Barcelona (entre ellos Antonio Centeno, activista del FVID; Alid Diaz, arquitecta; y Rai Vilatovà, antropologo y “manitas"), pero que a los pocoś meses enpezo a operar cono colectivo situado sumando a más personas (entre ellas el autor de estas líneas que pasó rápidamente de querer estudiar la experiencia como parte de un proyecto posdoctoral a participar activamente en el ro de documentador de la misma y su devenir).
- In this experience, we humanize urban space: by appropriating it, we talk about its dimensions,
its qualities, its architecture and its meaning.

- We make the city accessible, eliminating the barriers preventing us from deciding among all about the direction and intensity of our movements. We say: it's the city that must adapt to us and not women and men to it.

- Dwelling in the street, we demonstrate that we are all diverse (...). We are neither special, neither standard;

we're neither normal nor an anomaly (...).

- We move around in the city: we go through it thinking with the body, and with the body we move along politicizing the street. We are a flow of the city and we've abolished the

- Moving around (desplazándonos) in the city, we also displace (desplazamos) the sociat roles, the segregated We've been away from our homes for a while and we will not go back to being the same people anymore. We've abandoned the dead-end teritories that wer assigned to us"

(Commissió Diversitat Funcional BCN 15M, 2011).

In paratle, the Functional Diversity 'workgroup' of Madrid's Acampada Sol published another spatial intervention, of a more methodological kind: a guide on 'how to make accessible assemblies', which specified how to achieve inclusiveness by paying attention to different spatial and temporal dynamics, as well as those related tolanguage and modes or mintaction. Building from these interventions, maybe it was no surprise sut inited and developed concrete proposals for Medial abPradited and developed concrete proposals for Medialabcall for projects (an institution belonging to Madrid's City Hall, which has become one of the main engines in discussions and practices around open design and free culture in the countryy. This call had the purpose of fostering "proposals that could bring forth the design of objects, environments, and tools from the perspective of functional diversity, open design and open standards" (Medialab-Prado, 2012). These proposals were developed, presented and discussed with a small funding (ETS), a project that emerged in response to this call with the aim of building a kit to activate other relations between the wheelchair, its occupants, the surroundings and the bonds that had started to flourish within the $15 \mathrm{M}$; a project joining together different members of Barcelona's Functional Diversity Commission (namely, Antonio Centeno, FVID activist; Alida Díaz, architect; and Rai Vilatovà, anthropologist and craftsman) that after a few months started to operate as 'colectivo'", Located at the intersection between open design and functional diversity, apidly was turned from a postdoc researcher wanting to study

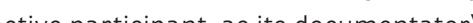


Lejos de una mera apelación a la fabricación digital distrribuida, en el particular contexto español el diseño abierto situado entre la reflexión anglosajona sobre el software libre, la tradición latinoamericana del saber popular y la reflexión marxista sobre los comunes, que eclosiono de formas bien interesantes a raiz del 15-M. Esto es, un conjunto de prácticas no solo vinculadas a una voluntad de publicar y permitir el acceso tambín a un experinentacín política con la apertura de formatos y los modos de abrir y los métodos del diseño (véase, para un relato más específico de esta cuestión en el ámbito de los colectivos españoles de arquitectura, el trabajo de Corsín Jiménez \& Estalella, 2016). ¿Pero qué implica el activismo de la diversidad para el diseño? O, mejor dicho, en este contexto donde la diversidad diversidad funcional abre el diseño?

\section{CACHARREAR EN TORNO A LA SILLA}

Para intentar ensayar una respuesta, relataré brevemente un pequeño proyecto que desarrolló ETS en 2014. Este
pequeño proyecto de construcción supuso el proceso de incorporación al colectivo de Marga Alonso, activista y miembro de la Oficina de Vida Independiente de Barcelona. Un proceso constructivo, pero también de diálogo entre Mar

\section{- Marg}

«Desde siempre, desde que tengo uso de razón, o desde cuando recuerdo, una mesa me ha resultado un importante punto de apoyo. Para manejarme con un libro, una libreta,

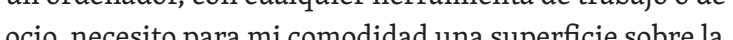
que poder apoyar mis manos a una altura suficiente a mi vista. Mi diversidad funcional se debe a una falta de masa muscular, sobre todo en las extremidades, y a una rigidez en las articulaciones. Por ello mis movimientos son a base de impulsos y con necesidad de puntos de apoyo [...] La Mesi, al igual que mis movimientos, fue un impulso. Una tarde, rescaté una imagen de mi silla, en el Paint dibujé una idea de mesa acoplada a mis silla y pasé la idea a ETS. Enseguida me de en la mesa tengo todas mis cosas a mi alcance ahora, en a calle, con La Mesi también estoy más a susto porque en ella puedo manejar con mucha más comodidad el móvil; ahora puedo leer en los trayectos o frente a diferentes paisajes, puedo asistir a cualquier evento cultural con 1 a seguridad de poder manejar apuntes, folletos y lo que se ofrezca. Antes de La Mesi mi minusculo punto de apoyo era el mando de conducir, y no es que necesitara mucho espacio
Far from being a mere vindication of distributed manufacturing, the specific context of Spain 'open design' should be considered a complex activist repertoire located at the crossroads of free sofware debates, the Latin American tradition of popular Whow the 15M. Than is it in very interesting ways as a consequence of publishing and allowing free access to the des not only aiming at materials, but also to a political experimentation 're-sourcing' the formats and the ways of opening the spaces, the infrastruct the and the methods of design (for a more specific account of this issue in the context of the Spanish architecture collectives, see the work of Corsín Jiménez \& Estalella, 2016) But, what does functional diversity activism imply for design
practice? or to say it otherwise, in this context where functional diversity and open design meet, how is functional diversity

opening up design?

\section{TINKERING EN TORNO A LA SILLA}

\section{(AROUND THE WHEELCHAIR)}

In an attempt to provide an answer to these questions, I will briefly describe a small ETS project developed in 2014. independent-living activist of intorporation of Marga Alonso, process, but also a dialogue between Marga and Alida, aTs architect, of whose final collective account I offer here a few fragments:

\section{-Marga}

Always, ever since I have the use of reason or I can remember, tables have been very important supporting points to me. To be able to handle a book, a notepad, a computer or any other tool for work or leisure, for my comfort I need a surface where I can tay my hands at a from a adacuate to my sight. My functional diversity stens rigidity of the joints. For this reason, my movements are impulsive and in need of supporting points (...) La Mesi, just like my movements, was an impulse. One afternoon, 1 retrieved a picture of my chair, drew over it in Paint an idea of a table docked to my chair, and passed the idea on to ETS. Alida instantly answered that we would make it, and now we have made it. Before La Mesi, I could only be comfy at home, where in my desktop I can have all $m y$

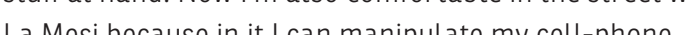
at ease: now I can read on my way to somewhere or front of different landscapes, I can attend any cultural event with the assurance that I'll be able to handle notes, brochures or whatever may be on offer. Before La Mesi, my minuscule supporting point was the joystick, and it's that I was in need of much more space, but I sure needed a space I could call my own"
«Lo primero como siempre fue encontrarnos entendernos, tomar medidas, fotos, tocar la silla, mirarl por abajo, su estructura, etc. Mirar detenidamente a ubicación, el tamaño y la forma que daríamos a las piezas. Con este primer encuentro hicimos dibujos de variantes $y$ construimos unas maquetas de papel, cartón, etc. Y probamos cosas relativas a alturas, tamaños, posiciones entre las distintas partes, por ejemplo;

- Las distancias entre el cuerpo y la tabla, entre el cuerpo y la estructura de sostén de la mesa;

- La altura para que la mano mesa, para que el joystick quede libre;

- La inclinación de la tabla para que Marga pueda leer con cierta comodidad;

- La ubicación para que esté alineada con su cuerpo; - La ubicación de la pieza de sujeción para que no la
moleste, en un espaciol libre entre sus piernas y que quede oculta por el cojin, etc.

Como resultado: en La Mesi nada está centrado, ni la mesa en relación al eje de la silla, ni la planchuela en relación tubo de sostén, ni la tabla en relación a la planchuela».

«Trabajamos con necesidades muy concretas, con requerimientos que a menudo estan muy definidos y son muy precisos. El resultado es que los objetos suelen ser muy personalizados, para cuerpos $y$ funcionamientos muy singulares (...) Pero aun siendo así, lo que buscamos con lo que pensamos, constrummos, probamos, etc., no ese funcion miento sino ctivar unas posibilid de relación con el entorno. No estamos atentas al cumplimiento de normas, sino a la plena capacidad de una singularidad. No están pensados para rehabilitar un cuerpo solo, sino para habitar nuestro entorno común; entonces están diseñados y construidos para y desde la diversidad funcional. Y por esto y por una convicción firme en la necesidad de compartir lo que hacemos para común, también hemos hecho un tutorial».

Como final del proceso, la propia Marga escribió el siguiente texto que se publicó en el blog de ETS:

«LA MES

Dadme un punto de apoyo y moveré el mundo, así de sencilla es la idea, la necesidad y la utilización de La Mes. construida con madera y hierro, encajada con 4 tornillos y una palometa, y sin más complicaciones.
"Like always, the first thing was meeting to understand each other; taking measurements and pictures; touching the chair, looking at it from underneath, its structure, etc,
taking, closer look at Marga and her chair discussing among all of us about the right place, the size and the shape we ll make the parts. With this first encounter we sketched out different versions and we built models out of paper, cardboard, etc.

And we tried out stuff related to the heights, sizes and relations between the different parts. For instance:

- The distances between the body and the board, the body and the structure supporting the table,

- The height for the hand to be placed comfortably over the table, or for the joystick to remain free;

- The inclination of the board so that Marga could read

with a certain degree of comfort;

- The position, so it is aligned with her body;

- The positioning of the fastening element in the free space between her legs, and hidden by the cushion so that

doesn't bother her, etc.

As a result: in La Mesi nothing is centred, neither the table in relation to the chair's axis, nor the plate in relation to

We work with very concrete needs, with requirements tha are very often well defined and very precise. The result is that objects tend to be personalized for very singular bodies and modes of functioning (...) But still, what we aim for with what we think, bunld, test, etc., is not only to get a activate the possibility to relate with our environments. We don't care about norm compliance, but giving full capacity to a singularity. They [the objects are not conceived torehabilitate a single body, but to dwell on our common environment; hence, they are designed and built for and from functional diversity. And for this reason and because of a firm conviction in the need to share what we do - so that anyone might work out his

As a closure to the process, Marga herself wrote the following text that was published in ETS' blog:

"LA MESI

Give me a place to stand and I shall move the world. That's the simplicity of the idea, the need and the use of $L a$ Mesi, and steel, attached with 4 screws and a butterfly wing nut with no further complications.

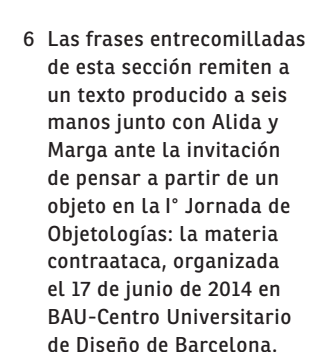

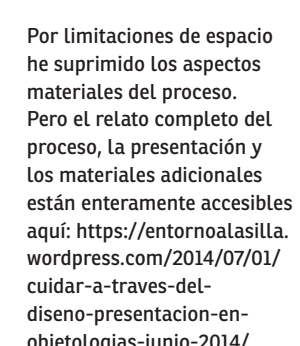
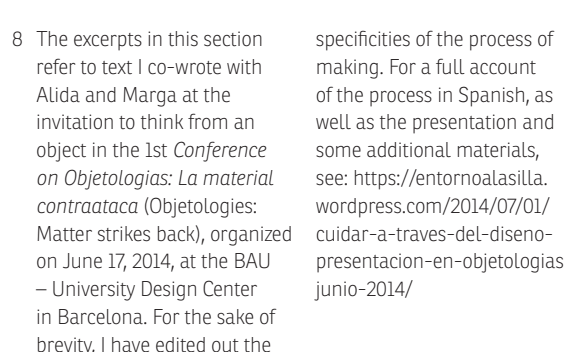

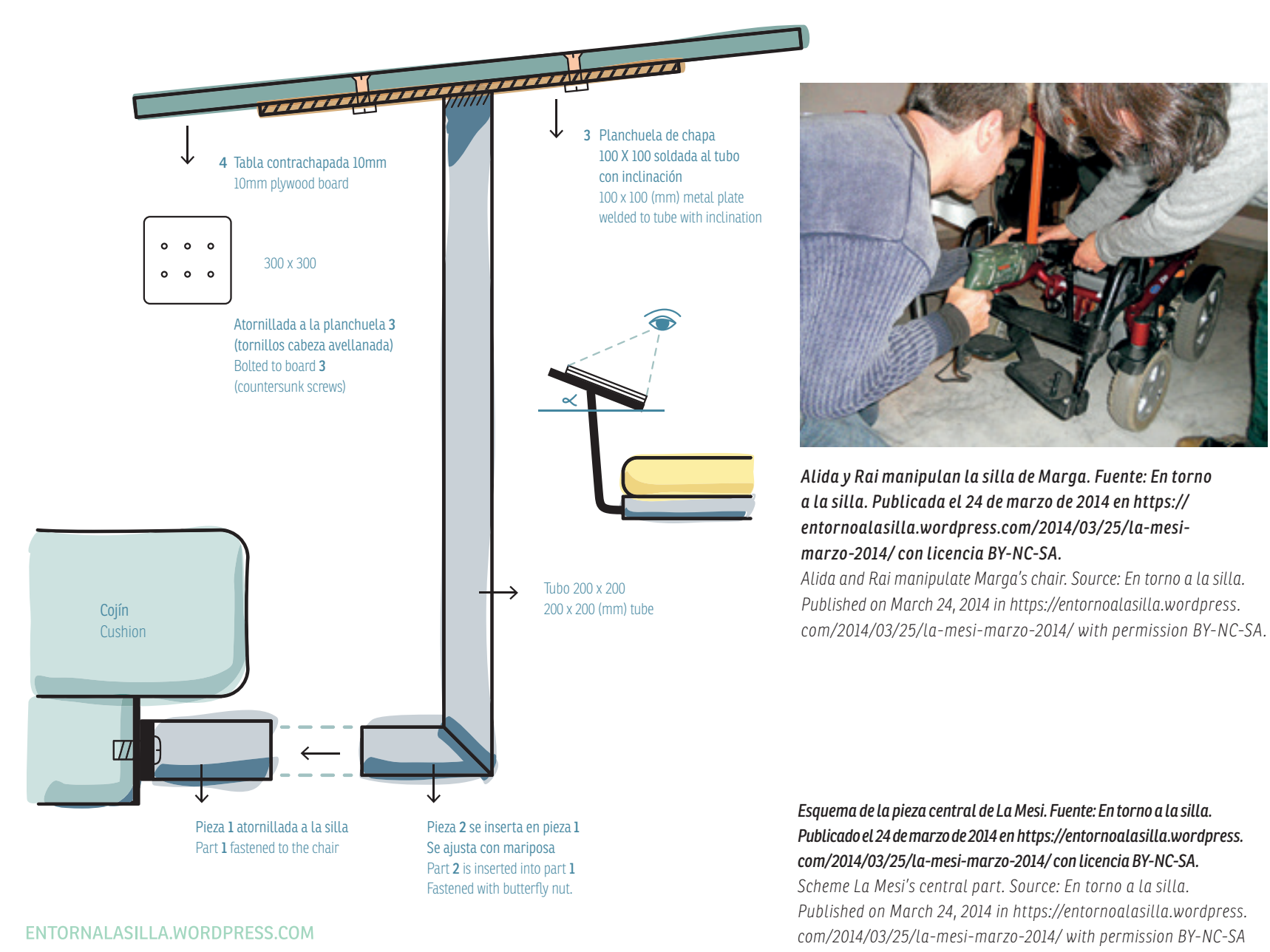

Aliday Rai manipulan la silla de Marga. Fuente: En tori

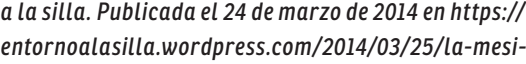
marrz-2014/ con licencia BY-NC-SA.

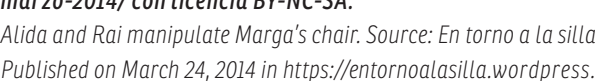

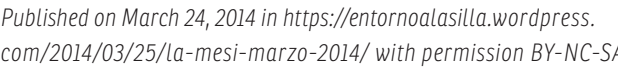

Esquema del apieza central de L L Mesi. Funte: Entorno alasilta

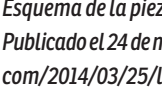

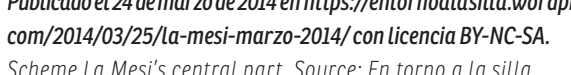

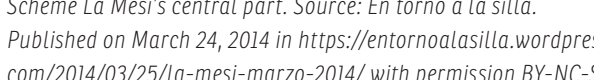

Una mesi a medida, porque no se coloca en algún lugar predeterminado de la silla, sino que se ha construidoy colocado en alineación a mi posición fisica, lo que da muchísimo juego: saber que quien manda no es el objeto, sino el sujeto. Yo, personalmente, y entiendo que cada Mesi puede ser única, comienzo mi aventura con ella leyendo y/o escribiendo bajo algún árbol o frente a cualquie mucha más comodidad-libertad, disfrutondo de

captación de fotografías».

\section{¿LA DIVERSIDAD FUNCIONAL COMO}

UNA POLLTICA DEL DISEÑ

- Es por lo que abren proyectos como La Mesi que consider que la diversidad funcional pudiera implicar una politica de diseño (y sobre todo del "diseño universal"), en el sentido que le da al término "politica" el filósofo Jacques Rancière.

Primeramente, el gesto que se inaugura en las plazas, y

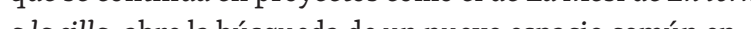
diversidad funcional. En este, la propia diversidad funciona opera como una forma de lo que Amador Fernández-Savater inspirándose en la figura de Rancière, denomina "ficción política", la que se caracteriza por rasgos como los siguientes:

Acustom-made mesi, because it isn't attached to any predetermined place in the chair, but has been built and placed aligned to my bodily posture, allowing a degree 列

, personally, and I understand that each mesi can be unique, begin my adventure with it reading and/or writing I will continue, now with much more comfort-liberty, to enjoy taking photographs".

FUNCTIONAL DIVERSITY AS

A POLITICS OF DESIGN?

It is because of what projects like La Mesi can open up that consider functional diversity may imply a politics of design (and especially of 'universal design', in the sense French philosopher

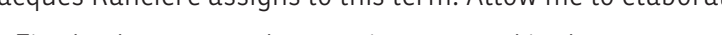
Firstly, the gesture that was inaugurated in the squares, and that is continued h projects like La Mesiby En torno a la diversity. In it functional diversity itself o perates as a a rint of what Amador Fernández-Savater, inspired by Rancière, calls 'political fiction', which: un terreno común, puesto que implica asumir "la causa del partir de la que se funda la posibilidad de un nuevo nosotros. experta de la producción de arreglos de diseño de las diversa vyudarnos entenderlas operaciones que diveridt preexistente o, incluso, frente al trabajo legal para la creación de la idea de un único diseño que acoja toda la diversidad de
«Redefine el mapa de lo posible: no sólo modifica lo que se puede ver, hacer, sentir y pensar acerca de la distribución jerárquica de lugares y funciones en nombre de las capacidades de cualquiera y la igualdad de las inteligencias. Muestra paisajes inéditos: hace ver cosas que no se veían, pone en relación lo que estaba disperso, hace surgir otras voces y otros temas, otros lenguajes y otras legitimidades y etrchas tros razonamientos, inédito a todos, a cualquiera (.) Las ficciones políticas crean terreno común, nos permiten dejar de ser lo que somos y encontrarnos "en tanto que" otra cosa, un nosotros abierto e incluyente» (Fernández Savater, 2012).

De hecho, ese "todos somos diversos funcionales" construy otro", lo que para Ranclere no es un humanitarismo mora relativo a la empatia y al ponerse en el lugar de los otros a respecto a un cierto siv que suele implicar una identificacion mposible, una identificación con otro con el cual al mismo tiempo, no puede ser identificadoy (Rancière, 2006 , pás. 34) a Ese terreno común, a su vez, permite distinguir claramente el activismo identitario del movimiento asociativo que se reúne en torno a la noción de discapacidad y una delegación experimentaciones en relación a la diversidad funcional. Qulítica y sudiferenciación de la noción de polićí pere a la funcional abre para el diseñ

"Redefines the map of the possible: not only modifies what can be seen, felt and thought about reality, but also of places and functions in the name of the capacities of anyone and the equality of the intelligences. It shows unprecedented landscapes: it allows to see things that were not seen, relates what was scattered, causes the emergence of voices and other issues, other languages reasoning, other legitimacies and other facts. And offers this new landscape to all, to anyone (....). Political fictions create a common ground, they allow us to stop being who we are and find ourselves 'as' something else, a 'we' that is open and inclusive" (Fernández Savater, 2012).

In fact, a stance like 'we are all functionally diverse' builds a common ground, since it implies assuming 'the cause of the

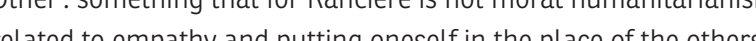
but to a "a refusal to identify with a certain self" which usually" implies "an impossible identification, an identification with an other with whom one cannot in normal circumstances identify" (Rancière, 1998, p. 28), from where the possibility of a new 'we' is founded. This common ground, in turn, allows us to clearly tell the associative movement's identity politics, which gathers aroun the notion of 'disability' and an expert delegation to produce design arrangements, from the different experimentations in relation to 'functional diversity'. Perhaps the particular meaning notion of police may help understand the openings that functiona diversity operates in design:

"the police (...) [is] a form of intervention which prescribes what can be seen and what cannot be seen, what can be said and what cannot be said. And politics is constructed in relation to that prescription. Politics is [...] declared in the face of policing, defined as the law that prescribes what emerges and what is heard, what can be counted and what cannot be counted" (Rancière, 1998, pp. 28-29. dechle y lo indecible. $Y$ es respecto a esta preschp que lapolitica se const tuye. La politica (...) se declara y de lo a la polcha, concebida como ley de lo que aparce (Rancière, 2006, pág. 33).

Frente a la policía de las "tecnologías de apoyo" y su ideal de inclusión de "las personas con discapacidad" en una sociedad de formas institucionalmente sancionadas de diseño univers (como los estándares urbanos, que suelen pensarse a partir potenciales usos), el cacharreo desde la diversidad funcional (modo vernaculo de entender la propia práctica de En torn a cualquiera punda acometer) irrumpe y ramp yice con (1) la lógica de mercado de productos para grupos de interés específicos $y / 0$ segregados - en un gesto donde la diferenci aparece categorizada, ordenada y legible (cuya mayor expresión la tenemos en el "WC para discapacitados", o en la politica de la identidad que distingue "tipos de discapacidad"
Against the background of the police of 'technical aids' and society; or even, the legat work for the creation of institutioxastent sanctioned forms of universal design (such as the urban standards conceived as singular designs accommodating the diversity of all potential uses), functional diversity's tinkering (cacharrear, a vernacular way of understanding the own practices of En torno a la silla, using this rather pejorative term to designate a tudic practice of fabrication and of making anyone can undertake) entalils a disruption: It breaks away from (I) the logic of the market difference appears categorized, ordered and legible (its greatest expression being the 'WC for the disabled', or the politics of ident if that distinguishes 'types of disability' according to the bio-medical 
según el discurso biomédico)-; o con (2) la búsqueda de soluciones omnicomprensivas, "universales" o "para todos" para aunar todas las diferencias (que en muchas ocasiones no hace sino aplanar y excluir), y que luego acaba necesitando estándar a la singularidad de movimientos de una persona El cambio de repertorio en el paso por las plazas ha colocado el concepto en otro lugar. Ya no es más unicamente un "concepto" auto-representacional positivo o meramente lingǘstico, sino que se conviete en un operador de constracción material de re materializaces singulares Evidencis un mera distint de ver o de abrir el mundo, dejando de ser solo una manera. peculiar en que las personas antiguamente denominadas "con discapacidad" se refieren a sí mismas para forjar una política de la identidad. A través del cacharreo se convierte en una apertura a una vida con otas personas, que une a gente muy diversa alrededor de un concepto universal que no solo produce soluciones univocas, sino mútitiples, como parte de una apuesta

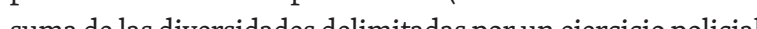
Pero, en segundo lugar, los efectos sobre el diseño son especialmente palpables porque, en casos como el proceso de tareas y con el fin y los medios de la tarea de diseñ. Por un porque se desdibujan por completo los roles establecidos de diseñador y usuario, donde Marga viene con una idea muy clara que otros le ayudan a construir, con el objetivo de poder segui haciendo crecer la relación que empiezan a compartir. Pero esta apertura colaborativa real, basada en asumir "la causa del otro" - con la distribución del poder concomitante que deben implicar este tipo de situaciones, de acuerdo con Jeremy Till la cual todos pueden hacer todo sino que supone una forma de hacer sumar las habilidades, los saberes y las experiencis convocadas, generando una situación "entre todos".

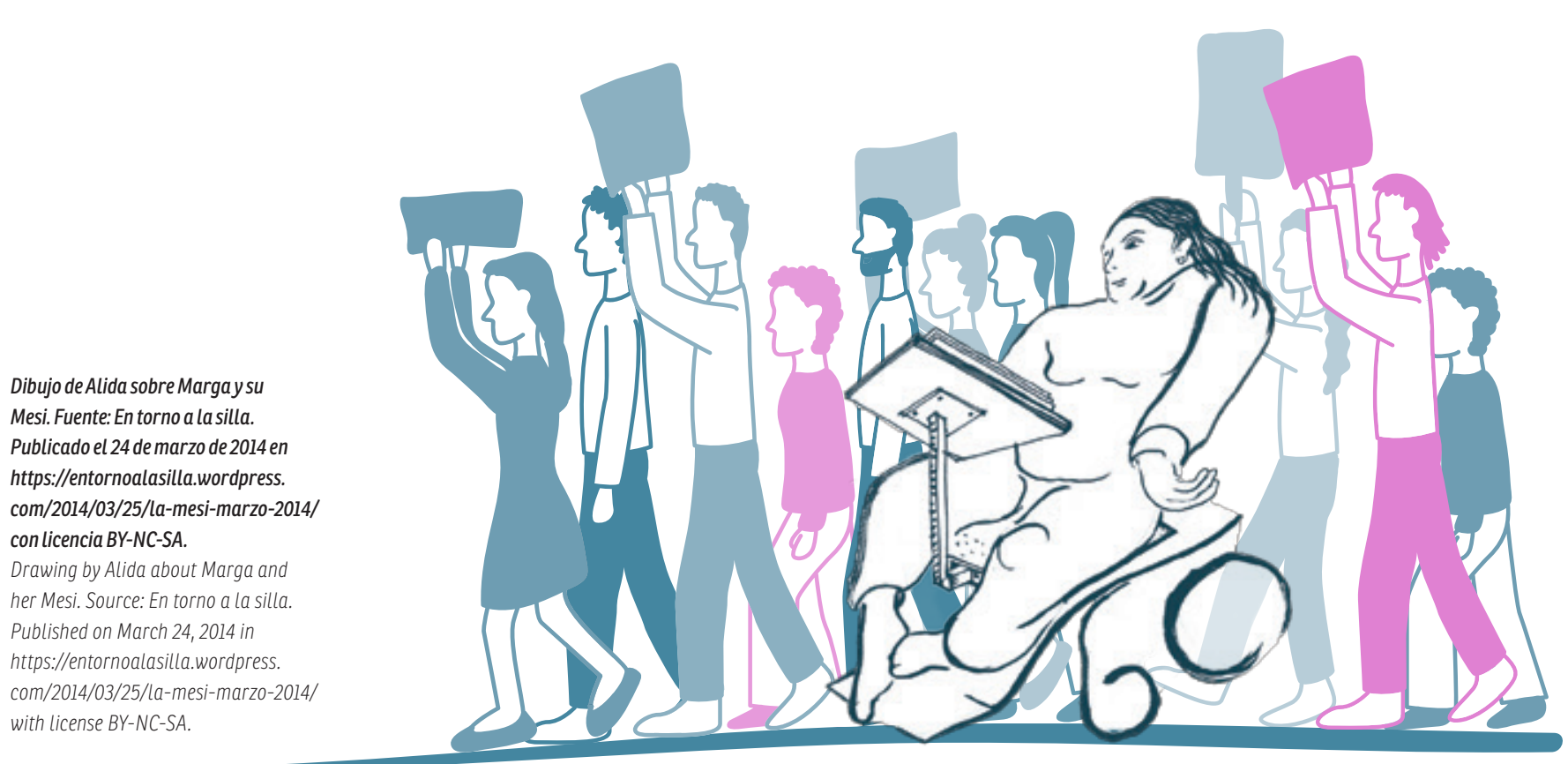

Pero también, porque el cacharreo - actividad permanentemente inacabada e inacabable - rompe con un fragilidad en las frad. Y a pesar de que esto implique una como La Mesi (un prototipo usable), se amplian lo decible y lo pensable acerca de quiénes, cómo y para qué se sienten convocados en un proceso de materialización. Tanto es así que quiza cacharrear desde la diversidad funcional implicaría del diseño en tanto coloca al diseño ante la cuestión de pensar no en usuarios y cómo ajustarlos con un producto más bien genérico, sino en términos de relaciones singulares $y$ donde lo relevante no es cómo el diseñador cataliza a través de su saber experto un buen producto, sino cómo conjugar y convocar las diferentes habilidades; pero una politica del diseño como tal, en tanto coloca en un hiato "si lo que necesitamos es un producto" "qué grado de finalización deben tener estas materializaciones", rompiendo con el pacto modernista de utilidad publica del disenoy con mundo comín en diversidad (Śńnchez Criado \& Cereceda un Lo que quiere decir que, frente al diseño universal y su proyecto de adecuar la singularidad desde productos "para todos", la vocación de universalidad de la diversidad funcional no puede sino tomar expresión en el diseño a partir de una radicad

apertura a la singularidad.

REFERENCES of design practice. On the one hand, because the established roles of 'designer' and 'user' are completely blurred: Marga the wuth a very clear idea that the others helped her build with the purpose of prolonging their nascent relationship. But this
concrete collaborative opening assuming the cause of the Othe - with the concomitant 'distribution of power' that these situations may imply, according to Jeremy Till (Upmeyer, 2015) - is not some banal democratzation whereby anyone could do anything. Instead, there present to generate a common situation 'among all'.

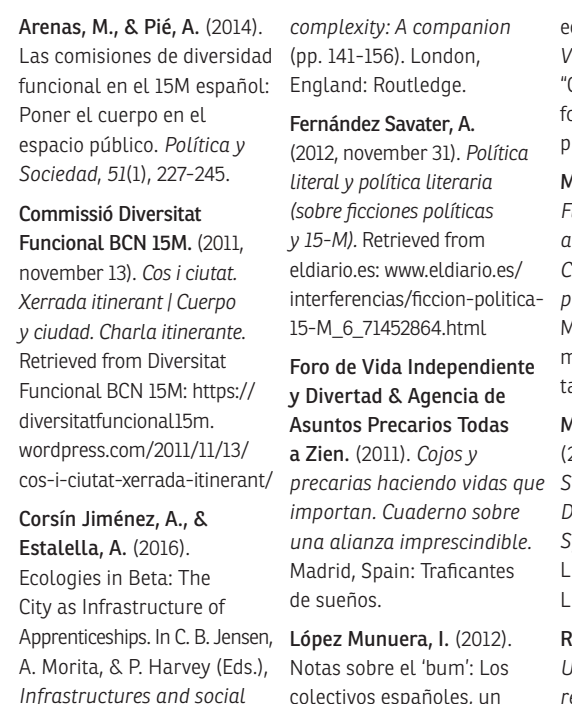

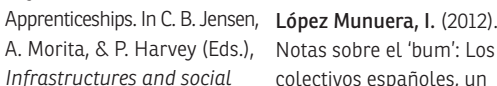

But also tinkering - a permanently unfinished and unfinishabte activit - breaks away from the idea of a final product. Indeed, small projects like La Mesi (a usable prototype) widen what might be speakable and thinkable about 'who', 'how' and 'what for' the feel summoned to a process of materialization. So much so that maybe tinkering from functional diversity would imply something different to user-centred designn.a pottics of design, allowing to generic product, but of singular relations where what is at stake is not how the designer might be able to synthesize a good product through his/her expert knowledge, but how to conjugate and convoke different skills. Indeed, a politics of design as such, to the extent that it holds in suspension 'the need for a product' or 'the degree of closure these materializations should have', breaking away from the modernist pact of public service of design. Hence becoming a fragile project of exploring the promises and compromises of materialy construeting a dverse conmon word contrast with universal design and its project to accommodate the existing singularity via products 'for all', functional diversity's universalist vocation, when taking a designerly expression, implies a radical opening to singularity.

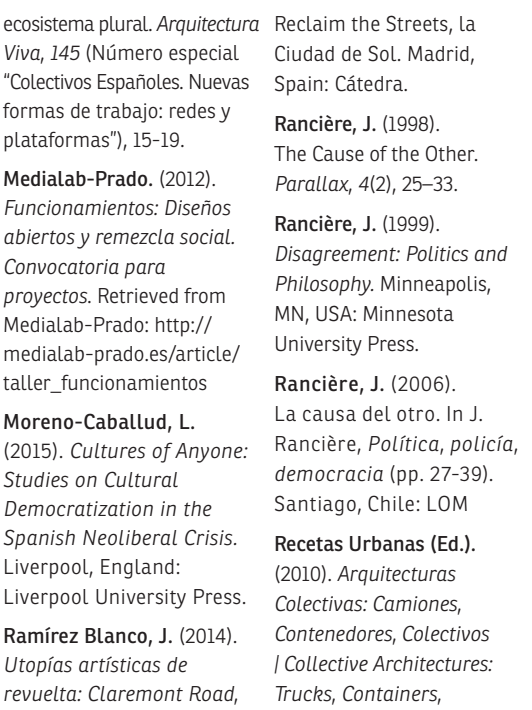

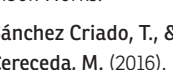
Urban accessibitity
issues: Technosicientific
democratizations at the

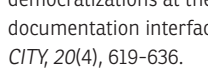
Upmeser, B. . 20215

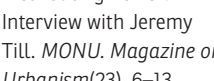
Werner, D. (E.d.). (1998).
Nothing About US Withou Us: Developing Innovation
Technologies For By, and With Disabled

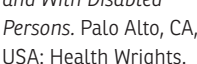

TOMÁS SÁNCHEZ CRIADO

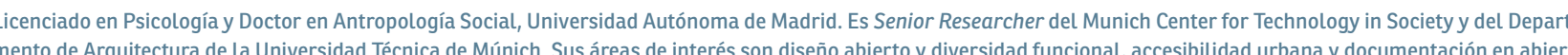
Entre sus publicaciones recientes destacan "Urban accessibility issues: Technoscientific democratizations at the documentation interface" (junto a M. Cerecedda, IIIT, vol.2.20

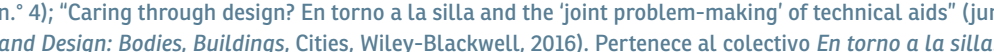

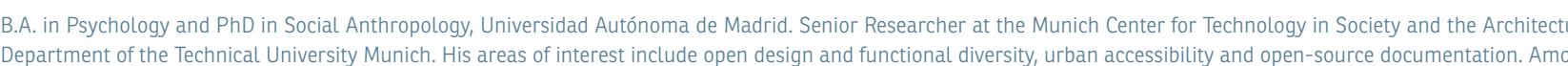

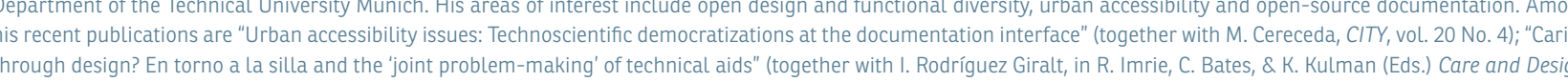

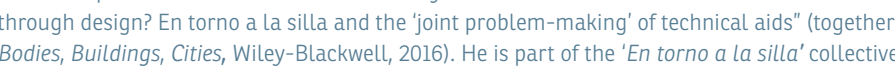

